\title{
The Concept of Law, Sixty Years On
}

\section{Enrique Benjamin R. Fernando, III}

\begin{abstract}
In 1961, H.L.A. Hart published his seminal work The Concept of Law, introducing what eventually became the most dominant, influential, but controversial, theory of law in the twentieth century. Not only did it revolutionize the way philosophy of law was done at the time, but it continues to raise fresh problems that puzzle even linguistic, moral, and political philosophers to this very day. The objective of this paper is twofold. The first is to survey four philosophical topics that were explored in The Concept of Law and the contemporary debates that have followed in its wake, and the second is to argue that while some of Hart's ideas have successfully withstood the tests of time and later critics, other ideas have not been as successful, but not without illuminating the path that legal philosophers must traverse in the twenty-first century. The paper has been divided into four parts. Part I ("Law and Method") shall explain the importance of the "internal point-of-view" to ongoing debates between descriptive and normative jurisprudence. Part II ("Law and Morality") shall explain how the rule of recognition revived the natural law/legal positivism debate, the result of which gave rise to the inclusive/exclusive legal positivism debate in turn. Part III ("Law and Language") shall discuss how Hart's insight into the "open texture" of language has created new problems about legal interpretation. Part IV ("Law and Obligation") shall discuss Hart's "practice theory of obligation" and how it has led modern writers to justify the duty to obey the law.
\end{abstract}

Keywords: H.LA. Hart, legal positivism, jurisprudential method, legal obligation

Herbert Lionel Adolphus Hart was the world's foremost legal philosopher in the twentieth century, and was also a major figure in political and moral philosophy .... . His work has often been tellingly criticized-indeed, one of the marks of his intellectual excellence lay in his encouragement of students who took strong exception to many of his ideas - but the 
magnitude of his achievements is beyond any reasonable doubt.

- Matthew Kramer and Claire Grant ${ }^{1}$

There can be no doubt that the questions Hart has revived so effectively are central to our understanding of the law and its social functions. Thus Hart has more than earned the rare compliment, that, had we not had his presence and contribution the field would not have looked the same.

- Ruth Gavison ${ }^{2}$

Herbert Hart's genius was to give the idea of law as rulesystem as clear and stylish an expression as one can well imagine. Many have followed where he led. Naturally, subsequent work has revealed flaws in the edifice, and periodic reappraisals and revisions have been called for. Different of us will seek to pursue a generally Hartian line of theorizing in different ways, and there can be no resting upon the text of 1961 as a last work or a sacred book...There remains much unfinished business, but what a start to the business that was.

- Neil MacCormick ${ }^{3}$

Hart was a pioneer...Pioneers always get a fair amount wrong .... Errors in legal philosophy are in general not so dangerous though there have been exceptions. For making mistakes as a pioneer he should not be judged too harshly. All this sounds like damning with faint praise, but that is not what I intend. Hart's The Concept of Law defined and continues to define the subject of analytical jurisprudence more than half a century since it was written. None of his critics or expositors, Dworkin, Raz, MacCormick, have written books which have in the least rivalled its position. And no rival work has been

\footnotetext{
${ }^{1}$ Matthew Kramer and Claire Grant, "Introduction," in The Legacy of H.L.A. Hart, ed. by Matthew Kramer, Claire Grant, Ben Colburn, and Antony Hatzistavrou (New York: Oxford University Press), xiii.

${ }^{2}$ Ruth Gavison, "Introduction," in Issues in Contemporary Legal Philosophy: The Influence of H.L.A. Hart, ed. by Ruth Gavison (Oxford: Clarendon Press, 1987), 5.

${ }^{3}$ Neil MacCormick, "The Concept of Law and 'The Concept of Law'," in Oxford Journal of Legal Studies, 14 (Spring, 1994), 23.
}

(c) 2021 Enrique Benjamin R. Fernando, III https://www.kritike.org/journal/issue 29/fernando december2021.pdf ISSN 1908-7330 
created out of the work of Kelsen. Hart's was an extraordinary achievement.

- A.W. Brian Simpson ${ }^{4}$

I n 1961, H.L.A. Hart, then Chair of Jurisprudence at the University of Oxford, published his seminal work The Concept of Law, ${ }^{5}$ introducing what eventually became the most dominant, influential, but controversial theory of law in the twentieth century. Not only did it revolutionize the way the philosophy of law was done back then, but it continues to raise fresh problems that puzzle philosophers to this very day.

The objective of this paper is twofold. The first is to survey four philosophical topics that were explored in The Concept of Law and the contemporary debates that have followed in its wake, and the second is to argue that while some of Hart's ideas have successfully withstood the tests of time and later critics, other ideas have not been as successful, but not without illuminating the path that legal philosophers must traverse in the twenty-first century. The paper has been divided into four parts. Part I ("Law and Method") shall explain the importance of the "internal point-of-view" to ongoing debates between descriptive and normative jurisprudence. Part II ("Law and Morality") shall explain how the rule of recognition revived the natural law/legal positivism debate, the result of which gave rise to the inclusive/exclusive legal positivism debate in turn. Part III ("Law and Language") shall discuss how Hart's insight into the "open texture" of language has created new problems about legal interpretation. Part IV ("Law and Obligation") shall discuss Hart's "practice theory of obligation" and how it has led modern writers to justify the duty to obey the law.

\section{Law and Method}

The Internal Point-of-View

The most celebrated theories of law that preceded Hart's were developed from the external point-of-view. These theories explained legal phenomena in terms of empirical facts from the perspective of third-party observers studying the behavior of participants within a legal system. John Austin's command theory of law, for instance, described law as a set of general commands issued by the sovereign of a state that are backed by a credible threat of coercive sanction in the event of non-compliance. ${ }^{6}$

\footnotetext{
${ }^{4}$ A.W. Brian Simpson, Reflections on The Concept of Law (New York: Oxford University Press, 2011), 205-206.

${ }^{5}$ H.L.A. Hart, The Concept of Law (Oxford: Clarendon Press, 1961).

${ }^{6}$ John Austin, The Province of Jurisprudence Determined and the Uses of the Study of Jurisprudence (Indianapolis: Hackett Publishing Company Inc., 1998), 24.

(c) 2021 Enrique Benjamin R. Fernando, III https://www.kritike.org/journal/issue 29/fernando december2021.pdf ISSN 1908-7330

(c) BY-NC-ND
} 
Meanwhile, Justice Oliver Wendell Holmes, an American legal realist, defined law as predictions of how judges will decide cases. For instance, he thought that laws could be expressed as conditional statements of the form, "If a man does $\gamma$, then judges will do $\chi .{ }^{\prime \prime} 7$ Alf Ross, a Scandinavian legal realist, explained law in behavioral terms, equating it with norms that judges believe are "socially binding." 8

Hart rejected these theories for different but related reasons. In his view, the problem with Austin's command theory is that it likened law to the orders of a gunman who obliges people to surrender their money. But in this scenario, when the gunman escapes, the threat of force vanishes with him, and his commands are no longer binding. Surely, law is not normative in this sense, for even when there are no officials who are physically present to enforce the law, citizens still acknowledge that they are under an obligation to comply with it. ${ }^{9}$ Meanwhile, Hart criticized Holmes's prediction theory for mischaracterizing how law bears upon the behavior of judges. When a judge is deciding whether a legal rule has been violated, he does not treat the rule as a statement of what he is likely to do to an offender. Rather, he treats the rule as a guide, reason, and justification to punish him..$^{10}$ Finally, the problem with Ross's theory is that it reduces legal obligation to a feeling of being socially pressured into conforming to widely accepted customs. Although such feelings may accompany obligations, they are not necessarily their source. ${ }^{11}$ Moreover, Hart explained in a separate article, if a judge says something like, " $\phi$ is the law," it cannot merely be an expression of what he believes about $\phi$. Rather, it is a recognition that $\phi$ is binding regardless of what he believes. ${ }^{12}$

The point of each objection is that law is not a purely external phenomenon that is explained in terms of sanctions, judicial practices, or habits. For Hart, law operates more like a rule than a habit, the main distinction being that only the former has an "internal" aspect. There is a difference between regular social behavior, such as when the members of a group have a habit of going to the cinema every Saturday, as opposed to rule-

7 Oliver Wendell Holmes, Jr., "The Path of the Law," in Harvard Law Review, 10 (1897), 458. Holmes's legal realism inspired several prominent American jurists whose views dominated American jurisprudence for much of the twentieth century. Among these was Justice Cardozo who argued that judges inevitably play the role of legislators and invent law: "The [legal] rules to which [judges] yield obedience are in truth not law at all. Law never $i$, but is always about to be." See Benjamin Cardozo, The Nature of the Judicial Process (New Haven: Yale University Press, 1921), 126.

${ }^{8}$ Alf Ross, On Law and Justice, ed. by Jakob Holtermann, trans. by Uta Bindreiter (Oxford: Oxford University Press, 2019), 45-46.

${ }^{9}$ Hart, Concept of Law, 19-25.

${ }^{10}$ Ibid., 11.

${ }^{11}$ Ibid., 88

${ }^{12}$ H.L.A. Hart, "Scandinavian Realism," in The Cambridge Law Journal, 17 (1959), 237.

(C) 2021 Enrique Benjamin R. Fernando, III

https://www.kritike.org/journal/issue 29/fernando december2021.pdf

ISSN 1908-7330

(cc) BY-NC-ND 


\section{THE CONCEPT OF LAW}

governed behavior, such as when they accept a rule to remove their hat in church. Hart identified a crucial difference between a habit and a rule: whereas a habit is not considered so important that it becomes a standard of behavior, a rule is accompanied by a "critical reflective attitude" that is espoused by members because they find good reasons for accepting it. ${ }^{13}$ For instance, the members of the community might make it a habit to watch a movie in the cinema every Saturday night, which, ultimately, is but a mere convergence of behavior. But they might have a rule for parishioners to remove their hats upon entering the church, the existence of which is considered to be a good reason for criticizing those who break it, and the violation of which would draw other people's ire and condemnation. Law, for Hart, was more like a rule. The externally observable regularity that constitutes a habit is a necessary condition for law but not a sufficient one. There must be an "internal aspect" that consists of a certain attitude.

If law really is a kind of social rule, then any satisfactory theory must explain legal phenomena from the "internal" point-of-view which consists of cognitive and volitional elements. ${ }^{14}$ The cognitive element exists when people are aware that they ought to behave in certain ways under certain conditions, such as how drivers know the rule to stop moving when stoplights turn red. Moreover, they do not view it as an arbitrarily imposed standard and appreciate the rationale of this rule, which is that it lowers the risk of accidents. as well as determine whether someone conforms to it. On the other hand, the volitional element exists when there is a desire for this pattern to be sustained. For example, drivers hope that others will follow the rule to stay on the right side of the road in order to avoid accidents. They also hope that those who disobey it will be sanctioned to deter reckless driving. In this sense, they have a "motivating reason" to avoid being punished. But they have another reason that is based on some interest whose realization depends on the cooperation of others - that roads will continue to be safe. In these situations, the rule is itself a reason to behave in certain ways because everyone behaves as prescribed. ${ }^{15}$ Similarly, for Hart, citizens accept law qua law; they presume there is no other reason necessary to observe a legal rule other than the fact that it is the law and organizes social life around certain patterns of behavior. Consequently, the internal point-of-view has been dubbed the "hermeneutic approach" 16 while The Concept of Law is considered

${ }^{13}$ Hart, Concept of Law, 54-56.

${ }^{14}$ Neil MacCormick, H.L.A. Hart, 2nd ed. (Stanford: Stanford University Press, 2008), 47.

${ }^{15}$ Sarah K. Paul, Philosophy of Action (New York: Routledge, 2021), 19-20.

16 P.M.S. Hacker, "Hart's Philosophy of Law," in Law, Morality, and Society: Essays in Honour of H.L.A. Hart, ed. by P.M.S. Hacker and Joseph Raz (Oxford: Oxford University Press, 1977), 12-18.

(c) 2021 Enrique Benjamin R. Fernando, III https://www.kritike.org/journal/issue 29/fernando december2021.pdf ISSN 1908-7330

(c) BY-NC-ND 
to have inaugurated the "hermeneutic turn" in legal theory. ${ }^{17}$ It emphasized the importance of going beyond describing law and its relation to society as a social scientist might ${ }^{18}$ to instead elucidate the conceptual frameworks that people use to think about law.

\section{Descriptive and Normative Jurisprudence}

In the last twenty years, Hart's critics have argued that investigating law "from the inside" is irreconcilable with his purportedly value-neutral method of "descriptive sociology."19 For them, a participant within the legal system does not merely conceive of law as rules; he is also interested in understanding what it is for, what makes it legitimate, and, most importantly for John Finnis, how it bears on practical reason - what one should do and what kind of person one should aspire to be. ${ }^{20}$ Obviously, this requires substantive argument about what justifies law, why we have it, or what its purpose is-questions, which, for Jules Coleman, ${ }^{21}$ constitute a "normative" jurisprudence, not a "descriptive" one.

Powerful arguments have been advanced for this view. Stephen Perry argues that Hart's descriptive constraints undermine his analysis of rules. For Perry, the notion of a "critical reflective attitude" only explains how people regard rules, but it does not explain why they are motivated to obey them. If Hart truly wanted to explain how rules are binding from the internal point-of-view, he says, then he should have argued how law creates obligations or what justifies its authority.22 Meanwhile, Jeremy Waldron argues that a theorist who gives an account of law from the internal point-ofview but does not endorse it himself fails to properly differentiate rules from other social norms. For example, like most believers, an atheist might be capable of objectively reporting what it means to believe in God's commandments, but this would still be a long way off from the testimony of

\footnotetext{
17 Scott Shapiro, "H.L.A. Hart," in A Companion to Analytic Philosophy, ed. by A.P. Martinich and David Sosa (Oxford: Blackwell Publishing Ltd., 2005), 170.

${ }^{18}$ Frederick Schauer makes a very compelling case for how legal theory benefits from advances in the social sciences. See Frederick Schauer, "Social Science and the Philosophy of Law," in The Cambridge Companion to the Philosophy of Law, ed. by John Tasioulas, 95-114 (Cambridge: Cambridge University Press, 2020).

${ }^{19}$ Hart, Concept of Law, v.

${ }^{20}$ John Finnis, "Describing Law Normatively," in The Collected Essays of John Finnis, Vol. 4: Philosophy of Law (Oxford: Oxford University Press, 2011), 31.

${ }^{21}$ Jules Coleman, "Methodology," in The Oxford Handbook of Jurisprudence and Philosophy of Law, ed. by Jules Coleman and Scott Shapiro (New York: Oxford University Press, 2002), 312 313.

22 Stephen Perry, "Hart's Methodological Positivism," in Hart's Postscript: Essays on the Postscript to the Concept of Law, ed. by Jules Coleman (New York: Oxford University Press, 2001), 348.
}

(C) 2021 Enrique Benjamin R. Fernando, III https://www.kritike.org/journal/issue 29/fernando december2021.pdf ISSN 1908-7330 


\section{THE CONCEPT OF LAW}

a Catholic believer who wholeheartedly accepts the commandments as reasons for action. Similarly, Waldron says, there is a difference between a descriptive account of law such as what a legal historian may provide, from a normative one that interprets its moral point, purpose, or justification. ${ }^{23}$ Finally, Brian Leiter thinks that clarifying our "shared" concepts is a fruitless endeavor because there are too many warring conceptions for a descriptive jurisprudence to handle. ${ }^{24}$ The problem, he explains, is that descriptive jurisprudence only measures the success of an account against "epistemic" values of theory-construction such as evidentiary adequacy, simplicity, and explanatory power. None of these, however, pick out which features of law are truly significant. They might be appropriate for determining which theory best explains the effects of laws on social behavior, but not for identifying which conceptual theory best distinguishes between habits and rules. Only moral and political values can do that by speaking to what law ought to be like. ${ }^{25}$

Despite these arguments, there are those who maintain that a descriptive jurisprudence is still worth undertaking. Grant Lamond replies that identifying the "best" explanations of phenomena from the internal point-of-view does not entail the use of justificatory terms. For instance, a theorist can describe a social practice which is regarded by community members to have a purpose. This purpose may either be universally agreed upon or challenged by other interpretations of that practice. But he can still develop his account without proposing a value to the practice himself. ${ }^{26}$ That is to say, he can describe how other people judge what law is without making any evaluations of his own. Julie Dickson's approach known as indirectly evaluative legal philosophy (IELP) has shown even greater promise in recent years. ${ }^{27}$ IELP does not deny that substantive argument is vital to a theory of law. It does, however, assume that it is worthwhile to separate description from evaluation. The descriptive aspect comes first, while the evaluative aspect is relegated to a later stage. On this approach, the first stage of inquiry consists of meta-theoretical concerns such as determining which features of law are necessary, how to ascertain truths about its nature, and which features are relevant to its evaluation. In no way do these questions demand

\footnotetext{
${ }^{23}$ Jeremy Waldron, "Normative (or Ethical) Positivism," in Hart's Postscript: Essays on the Postscript to the Concept of Law, ed. by Jules Coleman (New York: Oxford University Press, 2001), 425.

${ }^{24}$ Brian Leiter, "Legal Realism, Hard Positivism, and the Limits of Conceptual Analysis," in Hart's Postscript: Essays on the Postscript to the Concept of Law, ed. by Jules Coleman (New York: Oxford University Press, 2001), 368.

${ }^{25}$ Brian Leiter, "Beyond the Hart/Dworkin Debate: The Methodology Problem in Jurisprudence," in American Journal of Jurisprudence, 48 (2003), 34-37.

${ }^{26}$ Grant Lamond, "Methodology," in The Cambridge Companion to the Philosophy of Law, ed. by John Tasioulas (Cambridge: Cambridge University Press, 2020), 32.

${ }^{27}$ See Julie Dickson, Evaluation and Legal Theory (Oregon: Hart Publishing, 2001).
}

(c) 2021 Enrique Benjamin R. Fernando, III https://www.kritike.org/journal/issue 29/fernando december2021.pdf ISSN 1908-7330

(c) BY-NC-ND 
flat descriptive answers, but neither do they require normative ones. Rather, they require making indirect evaluations of law that will clear the way for its moral evaluation, criticism, and reform in later stages. ${ }^{28}$ For only after one determines the standards by which law ought to be judged can one commence with substantive argument. The value of IELP thus lies in its ability to lay solid foundations upon which substantive theorizing can proceed and to clarify the conceptual frameworks through which the legal philosopher frames his inquiries. Without these foundations, theories may become groundless, unjustified, assumptive, and prone to take moral conclusions for granted. But with them, they are able to preserve truths about law that must be accounted for.

In this dispute, I tend to side with the view that a descriptive jurisprudence is both possible and fruitful, the main reason being that a normative jurisprudence assumes a perspective that is too presumptuous, involved, and burdened with presuppositions that undermine the objectivity that is required of a jurisprudential theory. A general theory of law must be able to elucidate the concept of law, which, in turn, requires the logical analysis of legal concepts - what is presupposed by, what follows from, or what is implied by their use. More importantly, it is an inquiry into how these concepts facilitate one's understanding of law and how to best represent it. The normative jurisprudent, however, obfuscates his analysis from the start by assuming a specific moral and political point-of-view. He immediately takes pre-conceived notions of what law ought to be like and simultaneously explicates legal phenomena against these standards. But this is a long way off from first understanding what law is. It is one thing to develop substantive arguments about what justifies law or why the law of a society is morally illegitimate, and another thing entirely to carefully investigate the concept of law and its relation to society - regardless of its moral and political merit.

A general theory of law may consist of "detached legal statements." 29 These are propositions which, for instance, distinguish law from non-law, explain what makes law binding, account for the central functions of law, clarify how legal systems are structured, or describe what laws from jurisdictions have in common - all without carrying the force of full-blooded normative statements. Just as a lawyer may advise his client about his legal obligations without entailing that he believes that the law is always right, a descriptive jurisprudent may clarify the concept of law without endorsing its moral and political worth. He might, for example, theorize that laws are social conventions, that they are binding because they represent ways of life that

\footnotetext{
${ }^{28}$ Julie Dickson, “Ours is a Broad Church: Indirectly Evaluative Legal Philosophy as a Facet of Jurisprudential Inquiry," in Jurisprudence: An International Journal of Legal and Political Thought, 6 (2015), 220-230.

${ }^{29}$ Joseph Raz, "Legal Validity," The Authority of Law (Oxford: Clarendon Press, 1979), 155.

(c) 2021 Enrique Benjamin R. Fernando, III https://www.kritike.org/journal/issue 29/fernando december2021.pdf ISSN 1908-7330 


\section{THE CONCEPT OF LAW}

the community lives by, that their function is to protect public expectations of what is reasonable behavior, or that they are justified because they make social life predictable. None of these theories demand a commitment on his part; he must only account for the essential features of law-as-convention from a detached point-of-view. Furthermore, nothing prevents him from engaging in its evaluation afterwards so long as he separates his views of what law is from those of what it must be. Otherwise, he will fail to arrive at a concept of law that is truly representative of legal phenomena. It is thus important to arrive at a sound and logical understanding of legal phenomena before commencing with their normative justification.

\section{Law and Morality} The Rule of Recognition

The centerpiece of The Concept of Law is Hart's theory of law as the union of primary and secondary rules. This theory is classified under the tradition of legal positivism which holds that law is a matter of social fact and is conceptually distinct from morality. ${ }^{30}$ For Hart, law consists of two kinds of rules. Primary rules are those that are binding upon citizens and guide human behavior, such as the rule against murder or the rule that allows corporations to enter into contracts, while secondary rules are those that are binding upon the officials of the legal system and are concerned with the administration of the primary rules themselves. Among the latter are "rules of change" that direct lawmakers on the creation of primary rules and "rules of adjudication" that tell judges how to determine whether a primary rule has been broken. The most important secondary rule, however, is the "rule of recognition," a customary rule by which officials identify which primary rules are legally valid against multiple social-fact criteria such as their enshrinement as constitutional provisions, their enactment by rule-making bodies, or their having been laid down as precedents in judicial decisions. Any rule that does not satisfy at least one of these criteria cannot be valid, and thus, not law. Hence, it is the ultimate rule in any legal system insofar as it is a test that separates law from non-law. ${ }^{31}$

${ }^{30}$ Hart enumerated five theses that are often associated with positivism: (1) that laws are commands of human beings; (2) that there is no necessary connection between law and morals, otherwise known as the Separability Thesis; (3) that the analysis of legal concepts is (i) worth pursuing and (b) distinct from sociological, historical, and evaluative inquiries; (4) that a legal system is a closed logical system from which correct legal decisions can be deduced from predetermined legal rules; and (5) that moral judgments cannot be established as statements of fact by rational argument, evidence, or proof. See H.L.A. Hart, "Positivism and the Separation of Law and Morals," in Essays in Jurisprudence and Philosophy (Oxford: Clarendon Press, 1983), 5758.

${ }^{31}$ Hart, Concept of Law, 77-96.

(c) 2021 Enrique Benjamin R. Fernando, III https://www.kritike.org/journal/issue 29/fernando december2021.pdf

ISSN 1908-7330

(cc) BY-NC-ND 
Ronald Dworkin - Hart's student, greatest critic, and successor to the Chair of Jurisprudence - published an influential refutation of his positivism in an article titled "The Model of Rules," 32 which was subsequently retitled "The Model of Rules I" in his first collection of essays, titled Taking Rights Seriously. Dworkin's main criticism was that it is impossible for a "mechanical" master test of validity such as the rule of recognition to fully determine the content of law. The mistake, according to Dworkin, was to assume that every standard that is legally binding possesses social characteristics that satisfy the "pedigree" criteria laid out by the rule of recognition. Not everything that is law has been written as a constitutional provision, promulgated as a statute, or recognized as precedent. Only explicitly written black-letter rules fall under these categories.

But there is an unwritten class of standards, Dworkin says, that are nevertheless held by judges to be just as legally binding. These standards are known as principles, and they express requirements of justice, fairness, and equality, e.g., the principle that businesses have obligations unto their customers or that no man should profit from his own wrongdoing. Such principles may be so highly valued in society that they are enforced by judges as part of the law. Not all moral principles are legally binding, however; whereas rules apply in an "all-or-nothing" fashion, principles operate on the dimension of weight, of which they must possess a sufficient amount in order to be treated as law. ${ }^{33}$ The problem is that weights shift over time depending on their sense of appropriateness, rightness, or worth in the public eye, which means that they constitute a more nebulous, vague, and amorphous bundle of standards than rules.

Thus, for Dworkin, judges do not apply a test for law as straightforward as the rule of recognition. Rather, they apply what may be referred to as the "soundest theory test": a principle is part of the law if it figures into the soundest theory of rules. If a principle provides the best moral justification for a rule, then it is part of the law as well. ${ }^{34}$ For instance, although a car manufacturer may issue warranties that only explicitly hold them liable for the repair of defective parts, judges would find it unfair for them to skirt paying damages for injuries their customers incur in accidents caused by those parts. In this example, there is a principle that businesses cannot escape liability through contractual loopholes. Ultimately, then, the law for Dworkin consists of both black-letter rules and the moral principles that furnish their justification. But if this is true, then Hart's theory is fatally

\footnotetext{
${ }^{32}$ Ronald Dworkin, “The Model of Rules," in University of Chicago Law Review, 34 (1967).

33 Ronald Dworkin, "The Model of Rules I," in Taking Rights Seriously (London: Duckworth, 1977), 24-25.

34 Ronald Dworkin, "The Model of Rules II," in Taking Rights Seriously (London: Duckworth, 1977), 66-67.
} 


\section{THE CONCEPT OF LAW}

flawed, for the rule of recognition cannot capture all of the standards within the legal system and thereby fails to validate a significant portion of the law. It also means, contra positivism, that there is a necessary connection between law and morality - the law is whatever its morally best version is.

\section{The Inclusive/Exclusive Legal Positivism Debate}

Several writers have defended Hart by explaining how it is, in fact, possible for principles to be co-opted under the rule of recognition. Neil MacCormick argued that principles embedded in past decisions have acquired the status of judicial precedent, ${ }^{35}$ which confers them with a kind of social pedigree and thereby allows principles to enter the law by being linked to black-letter rules. Philip Soper, meanwhile, argues that nothing precludes the rule of recognition, apart from identifying which rules are valid, from picking out their respective justifications that judges agree upon as well. ${ }^{36}$ After all, it is a customary rule that reflects how they conventionally decide cases and need not impose any content-oriented restraints. For example, the rule of recognition might state that, "Cases where legal rule $X$ applies are to be decided as justice requires." As David Lyons suggests, it is already standard procedure for judges to test the validity of rules against constitutional provisions that contain moral terms such as "fairness" or "due process." 37 While the reasoning they engage is substantive, the fact of their convergence is a social one under the rule of recognition. Thus, Dworkin's objections affect no one.

The version of positivism that MacCormick, Soper, and Lyons endorsed is known as inclusive legal positivism, which claims that morality may figure into the determination of the existence, content, and meaning of valid laws. ${ }^{38}$ In no way is this a concession to Dworkin's view that law conceptually depends on morality. For the inclusive positivist, a rule of recognition that directs judges to decide cases as justice requires, for instance, is just as conceivable as one that never references morality, and the inclusion of moral criteria is only a contingent matter. Hart himself identified as an inclusive positivist in a postscript to a posthumously published edition of The Concept of Law:

\footnotetext{
35 Neil MacCormick, Legal Reasoning and Legal Theory (Oxford: Clarendon Press, 1978), 233.

36 Philip Soper, "Legal Theory and the Obligation of a Judge: The Hart/Dworkin Dispute," in Michigan Law Review, 75 (January 1977), 487-488.

${ }^{37}$ David Lyons, "Principles, Positivism, and Legal Theory," in The Yale Law Journal, 87 (December 1997), 425.

38 W.J. Waluchow, Inclusive Legal Positivism (New York: Oxford University Press, 1994), 2.

(c) 2021 Enrique Benjamin R. Fernando, III https://www.kritike.org/journal/issue 29/fernando december2021.pdf

ISSN 1908-7330
}

(c) $)$ BY-NC-ND 
First, [Dworkin] ignores my explicit acknowledgement that the rule of recognition may incorporate as criteria of legal validity conformity with moral principles or substantive values; so my doctrine is what has been called 'soft positivism' ...Secondly, there is nothing in my book to suggest that the plain-fact criteria provided by the rule of recognition must be solely matters of pedigree; they may instead be substantive constraints on the content of legislation such as the Sixteenth of Nineteenth Amendments to the United States Constitution respecting the establishment of religion or abridgments of the right to vote. ${ }^{39}$

Hart was so preoccupied with defending himself against Dworkin on his right flank that he failed to respond to that on his left. Joseph Raz, Hart's intellectual successor and torchbearer to the positivist tradition, introduced a "harder" version known as exclusive legal positivism which denies that moral criteria can ever be incorporated into the rule of recognition:

[The Sources Thesis]: A jurisprudential theory is acceptable only if its test for identifying the content of the law and determining its existence depend exclusively on facts of human behavior capable of being described in value-neutral terms, and applied without resort to moral argument. ${ }^{40}$

The Sources Thesis means that law is necessarily based on some kind of social source and never its moral content. It also means that value-laden tests such as "Cases where rule X applies are to be decided as justice requires" can never be part of the rule of recognition. Only source-based tests such as "Anything that Congress enacts is law" are acceptable. Thus, the inclusive/exclusive legal positivism debate turns on the question of whether moral criteria of validity can be incorporated into the rule of recognition. Whereas the inclusive positivist makes the weaker claim that law and morality are not necessarily connected, the exclusive positivist makes the stronger claim that law and morality are necessarily separated.

I argue that exclusive positivists have the upper hand in this dispute for the reason that inclusive positivists have failed to address them at the level

\footnotetext{
${ }^{39}$ H.L.A. Hart, The Concept of Law, 2nd ed., ed. by Peter Cane, Tony Honoré, and Jane Stapleton (New York: Oxford University Pres, 1994), 250.

${ }^{40}$ Joseph Raz, "Legal Positivism and the Sources of Law," The Authority of Law (Oxford: Clarendon Press, 1979), 37-38.
} 


\section{THE CONCEPT OF LAW}

of their arguments. While inclusive positivists have argued based on their interpretations of judicial behavior-for instance, that judges decide cases as if there were an inclusive rule of recognition-exclusive positivists have raised arguments that are more conceptual in nature; they show that even if judges behave in the ways that inclusive positivists describe, it would be fundamentally inconsistent with the very concept of law and its essential characteristics. The exclusive positivists' approach comes in two stages: first, it is to provide a rigorous analysis of law's essential features, and second, to determine their implications upon the limits of legal practice. Take for example Raz's longstanding view that inclusive positivism is inconsistent with law's conceptual claim to authority, ${ }^{41}$ which, for him, requires laws to express the views that are actually held by their sources-for if laws are interpreted in ways that were never endorsed, then they can no longer be regarded as authoritative. For example, the legislator who authored legal rule $\mathrm{X}$ may never have intended it to be interpreted "as justice requires." He may have intended its literal application even if it would lead to unjust consequences to protect public expectations. The inclusive positivist, however, in taking as his starting point the moral language and behavior of judges, believes it legitimate to treat some moral principles as law provided they are entailed by a combination of legal and moral premises even though no authority ever held this view. The problem is that a law that is entailed is not necessarily one that is endorsed, and if judges enforced norms that no authority figure had ever endorsed are binding, then the authority of law itself is undermined. ${ }^{42}$ The inclusive positivist, therefore, puts the cart before the horse. He first observes actual judicial practice - which by no means entails that it is being done correctly and does not preclude the possibility that judges may overstep their own bounds-and from there concludes that the rule of recognition must incorporate content-oriented criteria of validity. It is only later that he formulates his concept of law. The exclusive positivist's concept of law, conversely, preserves law's claim to authority; he treats as binding only those norms that satisfy a source-based test and only then is he able to draw the limits of law and develop a theory of legal practice and adjudication.

Inclusive positivists have failed to address the other conceptual arguments of exclusive positivists. Scott Shapiro argues that inclusive positivism is incompatible with law's function of providing practical guidance. For Shapiro, law is like a plan; it organizes the conduct of community members to achieve goals that have been decided for them in advance. For example, planning to go to the movies on Saturday eliminates

\footnotetext{
${ }^{41}$ Joseph Raz, The Morality of Freedom (New York: Oxford University Press, 1986).

${ }^{42}$ Joseph Raz, "Authority, Law, and Morality," in Ethics in the Public Domain (New York: Oxford University Press, 1994), 227-230.

(c) 2021 Enrique Benjamin R. Fernando, III https://www.kritike.org/journal/issue 29/fernando december2021.pdf ISSN 1908-7330
}

(cc) BY-NC-ND 
the need to contemplate whether one should go to the movies on the day itself. Similarly, law cuts off the need to ponder what portion of one's income needs to be paid in taxes, whether passengers should use a seatbelt, or how much employers should pay their employees. It tells them what to do and thereby makes a practical difference in the structure of deliberation. But if the existence of law is determined by the very facts it was designed to settlesuch as whether legal rule $X$ is binding because it is just-then it becomes incapable of making this difference because it is questioned and secondguessed.43 The exclusive positivist avoids this problem by eliminating content-oriented criteria of validity from the rule of recognition altogether. ${ }^{44}$ John Gardner, on the other hand, argues that relying on source-based criteria makes adjudication more determinate. Because morality is inherently controversial, moral criteria pertaining to justice are controversial as well. What is just for one judge is not necessarily just for another, making it difficult for judges to treat like cases alike. Source-based criteria, however, provide solutions to cases that cannot be resolved on their substantive merits. Granted, they may also be indeterminate and need to rely on the substantive merits of a case. But at least they narrow the range of relevant moral reasons that can be considered. ${ }^{45}$ Not all moral reasons are legal reasons, and a sourcebased test is needed to distinguish which ones are. It might be concluded that from a philosophical standpoint, the exclusive positivist has the upper hand. In elucidating a truer concept of law, he is better able to account for its authority, practical guidance function, and determinacy-essential features that the inclusive positivist somehow misses. What is needed from him is a more conceptual approach to legal theorizing; only then will it be clearer whether moral criteria of validity can, in fact, be incorporated into the rule of recognition without sacrificing what distinguishes law from other normative systems.

\section{Law and Language}

The "Open Texture" of Language

${ }^{43}$ Scott J. Shapiro, Legality (Cambridge: The Belknap Press of Harvard University Press, 2011), 274-275.

${ }^{44}$ In a later essay, Hart characterized legal rules as being "peremptory" and "contentindependent" reasons for action that foreclose independent deliberation on the merits of that action irrespective of its character. This, however, does not sit well with an inclusive rule of recognition which does require some moral deliberation. See H.L.A. Hart, "Commands and Authoritative Legal Reasons," in Essays on Bentham (New York: Oxford University Press, 1982), 253.

${ }^{45}$ John Gardner, "Legal Positivism: 51/2 Myths," in Law as a Leap of Faith: Essays on Law in General (Oxford: Oxford University Press, 2012), 36.

(c) 2021 Enrique Benjamin R. Fernando, III

https://www.kritike.org/journal/issue 29/fernando december2021.pdf

ISSN 1908-7330

(cc) BY-NC-ND 


\section{THE CONCEPT OF LAW}

There is an oft-criticized school of jurisprudence known as formalism which is associated with the following views: that law is valid in virtue of its form, that rules are applied independently of background reasons, that law is a gapless system, that all cases are regulated, and that adjudication is a matter of logical deduction.46 Jeremy Bentham is regarded as a formalist because he believed that the entire body of law could be codified into a comprehensive repository known as the Pannomion that covers every imaginable legal scenario. The law could be made so complete that judges would simply have to open the rule-book, locate the relevant statute, and apply it mechanically to decide cases. It would eliminate the need for adjudication. ${ }^{47}$ Hans Kelsen, though not quite a formalist himself, came close to depicting law as a closed logical system. In his view, law is a hierarchy of general and individual norms that are valid by virtue of norm-creating facts. For example, the judicial decision to hang a murderer is valid by virtue of a criminal law that inflicts the death penalty against murderers, which in turn is valid because it was created by the legislature, which in turn was authorized by the constitution to create statutes, and so on. ${ }^{48}$ If this is true, then judicial decisions can be deduced by simply invoking more general norms that authorize their creation.

Hart was mistakenly accused by Lon Fuller of formalism. ${ }^{49}$ In The Concept of Law, Hart explained that whereas most laws have central cases of application, there are also "cases of the penumbra" - borderline cases that may or may not fall under their ambit due to the "open texture" of language, 50 the existence of which create gaps in the law. For example, a rule prohibiting the entry of vehicles into a park may cover the standard case of an automobile. But there might be cases where people who bring bicycles, roller skates, or toy cars into the park are charged for violating that rule. These are borderline cases of the word "vehicle" because they possess some features of the central case but lack others. Judges can only consider whether they resemble the central case "sufficiently" in the "relevant" respects and must sometimes exercise discretion. For Hart, uncertainty at the margins is a

${ }^{46}$ Martin Stone, "Formalism," in The Oxford Handbook of Jurisprudence and Philosophy of Law, ed. by Jules Coleman and Scott Shapiro (New York: Oxford University Press, 2002), 170171.

${ }^{47}$ Jeremy Bentham, Of Laws in General, ed. by H.L.A. Hart (London: The Athlone Press, 1970), 246. See also, more recently, Gerald Postema, Utility, Publicity, and Law: Essays on Bentham's Moral and Legal Philosophy (New York: Oxford University Press, 2019), 172-173.

${ }^{48}$ Hans Kelsen, Pure Theory of Law, 2nd ed., trans. by Max Knight (New Jersey: The Lawbook Exchange, Ltd., 1967), 199-200.

${ }^{49}$ Lon L. Fuller, "Positivism and Fidelity to Law: A Reply to Professor Hart," in Harvard Law Review, 71 (February 1958), 638.

${ }^{50}$ Hart borrowed the term "open texture" from Friedrich Waismann. See Friedrich Waismann, "Verifiability," in Proceedings of the Aristotelean Society, Supplementary Volumes, 19 (1945), 121.

(c) 2021 Enrique Benjamin R. Fernando, III https://www.kritike.org/journal/issue 29/fernando december2021.pdf ISSN 1908-7330

(cc) BY-NC-ND 
general feature of language; because laws are formulated in general terms, there will inevitably be ambiguous applications. Moreover, lawmakers are only human; because times change and new cases arise, they cannot possibly foresee every case or linguistic fact to which legal rules apply. ${ }^{51}$

It is unsurprising that language was given prominence in The Concept of Law. Hart was part of the generation of Oxford philosophers who ushered in the university's golden age by developing a new method of analysis known as ordinary language philosophy..$^{52}$ Led by J.L. Austin ${ }^{53}$ and Gilbert Ryle, these philosophers studied words as they are used in ordinary conversations, their logical presuppositions, and their underlying concepts in order to clarify and dissolve philosophical problems that arise when, as Wittgenstein wrote, "language goes on holiday." 54 Likewise, Hart believed that the study of language would greatly benefit the study of law, i.e., studying the necessary and sufficient conditions in which sentences that contain legal terms such as "law," "rights," and "obligation" are true in order to find better ways of representing legal concepts. Like his colleagues, Hart may have believed that legal problems were linguistic at their core and thus called for linguistic solutions.

Alas, Hart's philosophical era and training led Dworkin to understand his theory as a linguistic study of the word "law." In his interpretation, positivism was merely an exercise in digging out the shared linguistic criteria that judges use to talk about law. But if shared linguistic criteria really did exist, then deep legal controversies such as those in court would never occur. There would only be trivial misunderstandings about the correct use of legal terms. In this sense, Dworkin insisted, Hart fell prey to the "semantic sting"; his theory fails to account for the existence of theoretical disagreement in legal practice by virtue of reducing jurisprudence to a linguistic enterprise when disputes are obviously more than semantic. ${ }^{55}$ But Dworkin was just wrong here. While language was important to Hart, it was not the end-all and be-all of his philosophy. Rather, he studied language to

${ }^{51}$ Hart, Concept of Law, 123-125.

52 Nicola Lacey, A Life of H.L.A. Hart: The Nightmare and the Noble Dream (Oxford: Oxford University Press, 2004), 132-151. See also, John Searle, "Oxford Philosophy in the 1950s," in Philosophy, 90 (2015), 174.

${ }^{53}$ Hart quoted J.L. Austin's famous words in The Concept of Law: "When we examine what we should say when, what words we should use in what situations, we are looking not merely at words...but also at the realities we use the words to talk about: we are using a sharpened awareness of words to sharpen our perception of, though not as the final arbiter of, the phenomena." See J.L. Austin, "A Plea for Excuses," in Philosophical Papers, 2nd ed., ed. by J.O. Urmson and G.J. Warnock (London: Oxford University Press, 1979), 182.

${ }^{54}$ Ludwig Wittgenstein, Philosophical Investigations, 4th ed., trans. by G.E.M. Anscombe, P.M.S. Hacker, and Joachim Schulte, ed. by P.M.S. Hacker and Joachim Schulte (West Sussex: Blackwell Publishing Ltd., 2009), 23.

${ }^{55}$ Ronald Dworkin, Law's Empire (London: Fontana Press, 1986), 33-46. 


\section{THE CONCEPT OF LAW}

understand how we talk about law, what it means to have rules, what is implied by terms such as "obligation," or, to borrow Timothy Endicott's term, to study the paradigms that we use to represent legal phenomena.. ${ }^{56}$ These tasks involve the study of words, but they are not just about the meaning of words. More importantly, they involve the study of concepts, which is why Hart titled his work The Concept of Law, not The Meaning of Law.

\section{Legal Interpretation}

Questions about language led to questions about meaning, which, in turn, lead to questions about interpretation. Recent scholarship has been preoccupied with questions such as whether there are "objectively true" interpretations of legal rules, whether it is possible to know which interpretations are correct, or how best to make sense of legal materials. ${ }^{57}$ Writers have offered different theories of interpretation to answer such questions.

Brian Bix recommends interpreting rules like Hart did-as social practices. On this view, the best interpretations of laws are those that reflect the practices upon which they are based, which entails that the contents of rules are derived from those of practices. For Bix, such interpretations are superior to those that need to posit metaphysical entities to make better sense of rules but only obfuscate them further. ${ }^{58}$ For instance, rather than interpreting a "duty of care" as if it corresponded to abstract entities that exist "out there" just waiting to be discovered, judges should examine how the law already imputes responsibilities unto parents, guardians, or schoolteachers. Kevin Toh, on the other hand, denies that practices have contents. ${ }^{59}$ Perhaps the psychological attitudes of those who participate in practices have contents, but not the practices themselves. They consist of nothing more than natural actions which, by themselves, underdetermine what the practice "really" consists of. But if this is correct, then practice-based interpretations actually posit entities just as spurious as those posited by ontological ones.

William Twining and David Miers-leaders of the Law in Context movement-advocate a more holistic approach to legal interpretation. According to their view, law, far from being a self-contained and autonomous

\footnotetext{
56 Timothy Endicott, "Herbert Hart and the Semantic Sting," in Hart's Postscript: Essays on the Postscript to The Concept of Law, ed. by Jules Coleman (New York: Oxford University Press, 2001), 41.

57 Andrei Marmor, "Preface," in Law and Interpretation: Essays in Legal Philosophy, ed. by Andrei Marmor (New York: Oxford University Press, 1995).

${ }^{58}$ Brian Bix, "Questions In Legal Interpretation," in Law and Interpretation: Essays in Legal Philosophy, ed. by Andrei Marmor (New York: Oxford University Press, 1995), 140.

${ }^{59}$ Kevin Toh, "Four Neglected Prescriptions of Hartian Legal Philosophy," in Law and Philosophy, 33 (2014), 708.
}

(c) 2021 Enrique Benjamin R. Fernando, III https://www.kritike.org/journal/issue 29/fernando december2021.pdf ISSN 1908-7330

(c) BY-NC-ND 
system, is inevitably shaped by social factors such as the community morality, cultural traditions, racial attitudes, religious beliefs, economic policies, and political goals. It is thus only fitting to interpret it in a manner that is sensitive to the situation of the interpreters, the backgrounds of the rules to be interpreted, and the broader societal context in which the interpretation takes place. ${ }^{60}$ Only then will the "best" interpretation emerge. But the problem with this approach is that it blurs the boundaries between legal and non-legal considerations. It is unclear whether law could maintain its claim to authority if it were so liberally conflated with social elements that are alien to it.

Other debates about legal interpretation are not just about the interpretation of law per se, but about its interpreters, namely judges. As Martha Nussbaum writes, judges are levied with a variety of charges. On one hand, they are accused of interpreting the law undemocratically when they seem to apply a majoritarian conception of democracy. For how can the "best" interpretation of law simply be determined by majority rule? Law would be no better than the tyranny of the mob. On the other hand, judges are also accused of politicizing law when their interpretations reflect the positions of the president who appointed them. This is aggravated by the fact that they are not elected officials and are therefore only indirectly accountable to the people. There is another accusation that judges are not fit to interpret the law, so they are better off deferring to legislators who know their own laws best. On this view, legislative intention should always factor into adjudication. ${ }^{61}$ This last point assumes, however, that there is such a thing as legislative intention and, more obscurely, that judges can discover what it is. What exactly is the content of this intention? It is unclear whether it is limited to the mental state of the lawmaker who authored the law, or whether it includes the entire host of non-homogeneous intentions that members of congress had when they voted a bill into legislation. If the latter, how would judges know which intention is the "true" one? It is possible for lawmakers to have had conflicting reasons for voting in favor of a bill.

The ongoing debates on legal interpretation are notoriously convoluted and have long branched away from their linguistic roots. They tend to draw insights from the philosophy of language, the philosophy of mind, the philosophy of psychology, and sometimes, even the philosophy of art or literature to better understand the nature of interpretation. In many debates, linguistic concerns have become merely secondary issues to be resolved. They cannot help but become a multidisciplinary hodgepodge of views, but this is a necessary step forward for any progress to be made or for

\footnotetext{
${ }^{60}$ William Twining and David Miers, How to Do Things with Rules, 5th ed. (Cambridge: Cambridge University Press, 2010).

${ }^{61}$ Martha Nussbaum, "Legal Reasoning," in The Cambridge Companion to the Philosophy of Law, ed. by John Tasioulas (Cambridge: Cambridge University Press, 2020), 72-73.
} 


\section{THE CONCEPT OF LAW}

a resolution to be arrived at. In no way does this mean that the study of language has become irrelevant to law; on the contrary, advances in the philosophy of language have contributed towards tremendous advances in jurisprudence in recent years. ${ }^{62}$ The takeaway, however, is that legal and linguistic philosophy no longer possess the internal resources necessary to solve some of their own problems. They must sometimes look beyond themselves for new answers, and Hart, it might be said, was guilty of underestimating the difficulty of some problems and overestimating the promise of language to solve them.

\section{Law and Obligation}

The Practice Theory of Obligation

A.J. Simmons defined obligations as requirements; they place limitations on our freedom but must nonetheless be obeyed. ${ }^{63}$ Hart made the stronger claim that obligations are moral requirements that may be incurred through the performance of voluntary acts. ${ }^{64}$ On this definition, then, legal obligations are moral requirements to obey the law, and the problem of legal obligation concerns the question of what justifies our duties to fulfill these requirements. ${ }^{65}$

Hart introduced a theory of obligation that was intimately connected with his practice theory of rules. In his view, one has an obligation when one is subject to the rules of a social practice. It was previously explained that a practice-rule exists when there is a social habit or widespread convergence of behavior, deviations from which are criticized by the members of a community. Additionally, these criticisms are seen as legitimate and the regularity itself is regarded as a standard for guiding behavior. But not all practice-rules give obligations. Hart listed three further requirements that must be satisfied in order for a practice-rule to be obligatory. They may be referred to as the "social pressure requirement," the "importance requirement," and the "conflict of interests requirement":

${ }^{62}$ See, for example, Andrei Marmor, The Language of Law (New York: Oxford University Press, 2014).

63 A.J. Simmons, Moral Principles and Political Obligations (New Jersey: Princeton University Press, 1979), 7.

${ }^{64}$ H.L.A. Hart, "Are There Any Natural Rights?," in The Philosophical Review, 64 (April 1955), 179 , note 1 .

${ }^{65}$ William Edmundson formulates this problem far more elegantly: "Why should I obey the law?" See William A. Edmundson, "Introduction," The Duty to Obey the Law, ed. by William A. Edmundson (Maryland: Rowman \& Littlefield Publishers, Inc., 1999), 1.

(c) 2021 Enrique Benjamin R. Fernando, III https://www.kritike.org/journal/issue 29/fernando december2021.pdf

ISSN 1908-7330

(c) $\mathrm{BY}-\mathrm{NC}-\mathrm{ND}$ 
The Social Pressure Requirement: The demand for conformity with these rules is insistent and the social pressure upon those who deviate is great;

The Importance Requirement: The rules are regarded as important because they are believed to be necessary to the maintenance of social life; and

The Conflict of Interests Requirement: It is recognized that the conduct required by these rules conflict with the interests of those who are under a duty to obey it. ${ }^{66}$

I shall argue that Hart has provided a flawed theory of obligation by discussing each requirement in turn, beginning with the social pressure requirement. In truth, it is doubtful whether the existence of social pressure is really a requirement for an obligation to exist. There are at least two reasons why. The first is that obligations often exist even when there is no social expectation for people to conform to a pattern of behavior. For example, vegetarians might be correct in saying that there is an obligation to refrain from eating meat because the slaughter of animals is unethical, even though they are a minority that is incapable of exerting a compelling amount of aggregate pressure. If this is true, then there cannot possibly be a social practice of refraining from eating meat, but the lack thereof would not necessarily nullify the existence of that obligation. Therefore, at least in some cases, the social pressure requirement is otiose. The second objection, as Leslie Green says, ${ }^{67}$ is that the fact that there is a general practice of $\varphi$-ing is not itself a reason for $\varphi$-ing. Just because everyone does something a certain way, it does not follow that one has an obligation to emulate them. Admittedly, there is often social pressure to conform to certain patterns of behavior, but it would hardly create a moral requirement. Otherwise, the existence of social pressure would be no better than the Austinian sanctions that Hart considered to be normatively inadequate. The pressure would only oblige people to behave in a certain way, but not place them under an obligation. In short, social pressure is neither a necessary nor sufficient requirement for an obligation to exist.

The importance requirement may be taken in conjunction with the conflict of interests requirement. In my interpretation of the importance requirement, a practice-rule gives an obligation when it upholds a prized feature of social life. Although obligations direct our actions towards these ends, they are not ordinarily thought of as things that one is eager to obey

${ }^{66}$ Hart, Concept of Law, 84-85.

${ }^{67}$ Leslie Green, "Law and Obligations," in The Oxford Handbook of Jurisprudence and Philosophy of Law, ed. by Jules Coleman and Scott Shapiro (New York: Oxford University Press, 2002), 518.

(c) 2021 Enrique Benjamin R. Fernando, III

https://www.kritike.org/journal/issue 29/fernando december2021.pdf

ISSN 1908-7330

(cc) BY-NC-ND 


\section{THE CONCEPT OF LAW}

because they usually entail making some kind of sacrifice or renunciation. For example, he who honors his obligations is often seen as someone who is morally praiseworthy because he is subordinating his personal interests for the greater good of a social group. Hence, the fusion of the importance and conflict of interests requirements is what enables Hart to characterize obligations as moral requirements. They guarantee that a practice-rule that is treated as obligatory serves a purpose that is so morally valuable that it becomes incumbent to conform to it. If this is correct, then law is a kind of moral standard as well, albeit one that is institutionally enforced. And it is precisely in virtue of being a moral standard that it is binding.

The problem, however, is that this argument rests on a sleight of hand. Hart was too quick to conclude that anything of great importance necessarily gives rise to obligations, be they moral or legal ones. It is entirely plausible that there are practice-rules that satisfy the importance and conflict of interests requirements but do not impose any moral requirements upon us. John Tasioulas, for example, thinks that there are moral actions that are supererogatory, but not obligatory. He gives the example of human rights defenders - such as those who work with non-governmental organizations or political groups-who publicly expose the rights-violating policies of oppressive regimes in order to reduce the number of future violations. ${ }^{68}$ What they do is of great moral importance, and by virtue of placing their lives in danger, it certainly conflicts with their personal interests. Yet they are not necessarily acting in conformity with any obligation; the reasons they have to put their own lives at risk do not outweigh the reasons they have to preserve their own life. A more familiar example might be that of a passerby who sees a child who is trapped in a burning building but reluctantly decides, in accordance with his best judgment, that it would be imprudent for him to risk his own life to save that of the child-even if, for instance, there were a social practice of always trying to save the life of a neighbor in that community. Doing so might have been morally praiseworthy and in conformity with a social practice of great importance, but it would hardly be morally obligatory. The point of these examples is that not every moral standard is the source of an obligation, and so it is important for us to distinguish an act that is morally praiseworthy from one that is morally obligatory. Thus, even if the importance and conflict of interests requirements do render the law a kind of moral standard, this fact by itself cannot be the main reason that it is obligatory. This is not to deny that there is such a thing as legal obligation. It only means that one cannot make the illicit inference from saying that if a

${ }^{68}$ John Tasioulas, "Hart on Justice and Morality," in Reading HLA Hart's 'The Concept of Law', ed. by Luís Duarte d'Almeida, James Edwards, and Andrea Dolcetti (Oxford: Hart Publishing, 2013), 173-174.

(c) 2021 Enrique Benjamin R. Fernando, III https://www.kritike.org/journal/issue 29/fernando december2021.pdf ISSN 1908-7330

(c) $)$ BY-NC-ND 
practice-rule is moral, then it is obligatory for the very same reason. Hart's practice theory of obligation fails.

\section{Contemporary Debates on Legal and Moral Obligation}

Philosophers who ascribe more plausible theories of obligation to Hart may be divided into two camps. Some opt to abandon the practice theory altogether, while others propose modifying it instead. The former have pointed out that Hart's argument from "fair play" in a paper that was published before The Concept of Law presents a promising framework for such a theory. On this view, whenever a group of persons consent to restrict their individual liberties according to the rules of an enterprise (e.g., a legal system), they have a right to similar submission from those who have benefitted from their actions. ${ }^{69}$ Matthew Kramer does not think this argument is sound, however, for it assumes that the benefits and burdens of rendering obedience unto the law are equally distributed throughout society..$^{70} \mathrm{He}$ argues that the principle of fair play is invalid because the playing field is not level to begin with.

Kenneth Einar Himma is of the latter group that prefers to add minor adjustments to Hart's theory instead. In particular, Himma addresses the objection that coercive enforcement-which presumably includes but is not limited to social pressure-cannot be a source of obligation. He agrees that coercion by itself does not give rise to obligations, so he adds a further requirement as a remedy: that a coercive system must be authorized to apply certain sanctions against non-feasance. The act of authorization, in turn, consists of what Himma refers to as the "acquiescence" of citizens to the application of the system. They do not necessarily have to exhibit a deferential attitude towards the legal system, for it is sufficient that they passively abide by its norms. Thus, a system of coercion and its authorization together create the conditions for legal obligation to exist. ${ }^{71}$ Unfortunately, in my estimation, Himma's argument is not persuasive because the force of acquiescence is too docile to equal that of authorization. For instance, a group of villagers may acquiesce to contribute a portion of their earnings each week to the mayor who is raising funds for the feast day of the town's patron saint. The villagers

\footnotetext{
${ }^{69}$ Hart, "Are There Any Natural Rights?," 185, note 67.

${ }^{70}$ Matthew Kramer, "Legal and Moral Obligation," in The Blackwell Guide to the Philosophy of Law and Legal Theory, ed. by Martin P. Golding and William A. Edmundson (Oxford: Blackwell Publishing Ltd., 2005), 181.

${ }^{71}$ Kenneth Einar Himma, "A Comprehensive Hartian Theory of Legal Obligation: Social Pressure, Coercive Enforcement, and the Legal Obligations of Citizens," in Philosophical Foundations of the Nature of Law, ed. by Wil Waluchow and Stefan Sciaraffa (Oxford: Oxford University Press, 2013), 172-178.
} 


\section{THE CONCEPT OF LAW}

might tolerate his system, but it does not mean that they are happy with it, or at least, they would hardly describe themselves as genuinely authorizing it. But then this would mean that the conditions for an obligation to exist are not satisfied. The problem, in short, is that acquiescence is too weak a requirement for obligation. If it is indeed a requirement, then Himma must defend something stronger such as obedience or deference to the system.

Finally, philosophers who belong to neither camp believe that Hart's analysis of obligation is unduly formal and deny that an explanation of obligation can be exhausted by facts about institutionalized practices alone. Nicos Stavropoulos points out that there are substantive theories of obligation which, if true, would strip the directives of legal institutions of their prima facie obligatory force. The mere existence of a social practice, even if it satisfied all of the aforementioned conditions, would always be an insufficient ground for justifying the existence of a legal obligation. Rather, Stavropoulos says, substantive considerations such as moral principles are what make the law binding. ${ }^{72}$ For example, legal obligations would exist not because there is any convergent practice that generates pressure to conform to protect some kind of social good, but because they promote justice, fairness, or equality. Admittedly, this line of reasoning squares with our common understanding of obligation - that we ought to follow the law because it upholds a moral purpose. Defenders of Hart need to account for this argument; there is promise, for instance, in arguing that moral principles are institutionalized as part of social practices. This article, however, is not the place to explore this route.

\section{Conclusion}

In this article, I have argued that while some of Hart's ideas have successfully weathered the powerful assaults of his critics, others are in need of serious revision if they are to continue to remain relevant to contemporary debates in legal philosophy. First, in relation to the debate on descriptive and normative jurisprudence, I have argued that Hart's "descriptive sociology" remains a plausible philosophical method of theorizing about law. Second, in relation to the legal positivism debate, however, I have argued that Hart and other inclusive positivists have failed to recognize the arguments of exclusive positivists for what they really are-conceptual arguments - a failure that led them to develop faulty conceptions of law. Third, in relation to language, I have argued that while Hart correctly pointed out that issues of legal interpretation are linguistic, the philosophy of language does not possess the

${ }^{72}$ Nicos Stavropoulos, “Obligations, Interpretivism, and the Legal Point of View," in The Routledge Companion to Philosophy of Law, ed. by Andrei Marmor (New York: Routledge, 2017), $77-82$.

(c) 2021 Enrique Benjamin R. Fernando, III https://www.kritike.org/journal/issue 29/fernando december2021.pdf ISSN 1908-7330

$((c))$ BY-NC-ND 
resources necessary to resolve them and must therefore be supplemented by the philosophy of mind, art, psychology, and even literature. Finally, I have argued that Hart's practice theory of obligation does not provide a persuasive account of our duty to obey the law but that his modern sympathizers have made ingenious attempts to improve it to varying degrees of success.

Hart undoubtedly made tremendous advances in jurisprudence when he published The Concept of Law sixty years ago. It is likely that the most tightly contested legal debates another sixty years from now will continue to be organized around the themes of his book, and so we are indebted to him upon whose intellectual shoulders we continue to stand. When Hart passed away on 19 December 1992, obituaries were published in all of the major broadsheets in England. In a memoir written for the British Academy, Tony Honoré referred to Hart as "the outstanding British legal philosopher of the twentieth century."73 In February 1993, a public memorial was held to commemorate the life of legal philosophy's intellectual giant. Zenon Bankowski shared a poem that was published in The Independent: a somber but poignant reflection on the impact that Hart had made on legal theory in the last half century:

Then, there was only him.

Now, a hundred flowers bloom.

This is his lasting contribution. ${ }^{74}$

Department of Philosophy, University of the Philippines-Diliman

\section{References}

Austin, J.L., Philosophical Papers, 2nd ed., ed. by J.O. Urmson and G.J. Warnock (London: Oxford University Press, 1979).

Austin, John, The Province of Jurisprudence Determined and the Uses of the Study of Jurisprudence (Indianapolis: Hackett Publishing Company Inc., 1998).

Bankowski, Zenon, "Obituary: Professor Herbert Hart," in The Independent (23 December 1992), <https://www.independent.co.uk/news/people/ obituary-professor-herbert-hart-1565229.html>.

Bentham, Jeremy, Of Laws in General, ed. by H.L.A. Hart (London: The Athlone Press, 1970).

\footnotetext{
${ }^{73}$ Tony Honoré, "Herbert Lionel Adolphus Hart (1907-1992)," in Proceedings of the British Academy, 84 (1994), 295.

74 Zenon Bankowski, “Obituary: Professor Herbert Hart," in The Independent (23 December 1992), <https://www.independent.co.uk/news/people/obituary-professor-herberthart-1565229.html>.
}

(C) 2021 Enrique Benjamin R. Fernando, III https://www.kritike.org/journal/issue 29/fernando december2021.pdf ISSN 1908-7330 


\section{THE CONCEPT OF LAW}

Bix, Brian, "Questions In Legal Interpretation," in Law and Interpretation: Essays in Legal Philosophy, ed. by Andrei Marmor, 137-154 (New York: Oxford University Press, 1995).

Cardozo, Benjamin, The Nature of the Judicial Process (New Haven: Yale University Press, 1921).

Coleman, Jules, "Methodology," in The Oxford Handbook of Jurisprudence and Philosophy of Law, ed. by Jules Coleman and Scott Shapiro, 311-352 (New York: Oxford University Press, 2002).

Dickson, Julie, Evaluation and Legal Theory (Oregon: Hart Publishing, 2001). "Ours is a Broad Church: Indirectly Evaluative Legal Philosophy as a Facet of Jurisprudential Inquiry," in Jurisprudence: An International Journal of Legal and Political Thought, 6 (2015).

, "Does it Matter Where We Start?: Some Remarks on Some Remarks by John Gardner on the Methodology of Legal Philosophy," in Jerusalem Review of Legal Studies, 19 (2019).

Dworkin, Ronald, "The Model of Rules," in University of Chicago Law Review, 34 (1967).

Taking Rights Seriously (London: Duckworth, 1977). , Law's Empire (London: Fontana Press, 1986).

Edmundson, William A. "Introduction," in The Duty to Obey the Law, ed. by William A. Edmundson, 1-15 (Maryland: Rowman \& Littlefield Publishers, Inc., 1999).

Endicott, Timothy, "Herbert Hart and the Semantic Sting," in Hart's Postscript: Essays on the Postscript to the Concept of Law, ed. by Jules Coleman (New York: Oxford University Press, 2001).

Finnis, John, "Describing Law Normatively," in The Collected Essays of John Finnis, Vol. 4: Philosophy of Law, 23-45 (Oxford: Oxford University Press, 2011).

Fuller, Lon L., "Positivism and Fidelity to Law: A Reply to Professor Hart," in Harvard Law Review, 71 (February 1958).

Gardner, John, Law as a Leap of Faith: Essays on Law in General (Oxford: Oxford University Press, 2012).

Gavison, Ruth, "Introduction," in Issues in Contemporary Legal Philosophy: The Influence of H.L.A. Hart, ed. by Ruth Gavison, 1-5 (Oxford: Clarendon Press, 1987).

Green, Leslie, "Law and Obligations," in The Oxford Handbook of Jurisprudence and Philosophy of Law, ed. by Jules Coleman and Scott Shapiro, 514547 (New York: Oxford University Press, 2002).

Hacker, P.M.S., "Hart's Philosophy of Law," in Law, Morality, and Society: Essays in Honour of H.L.A. Hart, ed. by P.M.S. Hacker and Joseph Raz, 1-25 (Oxford: Oxford University Press, 1977).

(c) 2021 Enrique Benjamin R. Fernando, III https://www.kritike.org/journal/issue 29/fernando december2021.pdf ISSN 1908-7330

(cc) BY-NC-ND 
Hart, H.L.A., "Are There Any Natural Rights?," in The Philosophical Review, 64 (April 1955). "Scandinavian Realism," in The Cambridge Law Journal, 17 (1959). The Concept of Law (Oxford: Clarendon Press, 1961). , Essays on Bentham (New York: Oxford University Press, 1982). , Essays in Jurisprudence and Philosophy (Oxford: Clarendon Press, 1983).

The Concept of Law, 2nd ed., ed. by Peter Cane, Tony Honoré, and Jane Stapleton (New York: Oxford University Pres, 1994).

Himma, Kenneth Einar, "A Comprehensive Hartian Theory of Legal Obligation: Social Pressure, Coercive Enforcement, and the Legal Obligations of Citizens," in Philosophical Foundations of the Nature of Law, ed. by Wil Waluchow and Stefan Sciaraffa, 152-182 (Oxford: Oxford University Press, 2013).

Holmes, Oliver Wendell Jr., "The Path of the Law," in Harvard Law Review, 10 (1897).

Honoré, Tony, "Herbert Lionel Adolphus Hart (1907-1992)," in Proceedings of the British Academy, 84 (1994).

Kelsen, Hans, Pure Theory of Law, trans. by Max Knight, 2nd ed. (New Jersey: The Lawbook Exchange, Ltd., 1967).

Kramer, Matthew, "Legal and Moral Obligation," in The Blackwell Guide to the Philosophy of Law and Legal Theory, ed. by Martin P. Golding and William A. Edmundson, 179-190 (Oxford: Blackwell Publishing Ltd., 2005).

Kramer, Matthew and Claire Grant, "Introduction," in The Legacy of H.L.A. Hart, ed. by Matthew Kramer, Claire Grant, Ben Colburn, and Antony Hatzistavrou, xiii-xviii (New York: Oxford University Press).

Lacey, Nicola, A Life of H.L.A. Hart: The Nightmare and the Noble Dream (Oxford: Oxford University Press, 2004).

Leiter, Brian, "Legal Realism, Hard Positivism, and the Limits of Conceptual Analysis," in Hart's Postscript: Essays on the Postscript to The Concept of Law, ed. by Jules Coleman, 355-370 (New York: Oxford University Press, 2001).

"Beyond the Hart/Dworkin Debate: The Methodology Problem in Jurisprudence," in American Journal of Jurisprudence, 48 (2003).

Lamond, Grant, "Methodology," in The Cambridge Companion to the Philosophy of Law, ed. by John Tasioulas, 17-37 (Cambridge: Cambridge University Press, 2020).

Lyons, David, "Principles, Positivism, and Legal Theory," in The Yale Law Journal, 87 (December 1997).

(c) 2021 Enrique Benjamin R. Fernando, III

https://www.kritike.org/journal/issue 29/fernando december2021.pdf

ISSN 1908-7330 


\section{THE CONCEPT OF LAW}

MacCormick, Neil, Legal Reasoning and Legal Theory (Oxford: Clarendon Press, 1978).

"The Concept of Law and "The Concept of Law'," in Oxford Journal of Legal Studies, 14 (Spring, 1994).

H.L.A. Hart, 2nd ed. (Stanford: Stanford University Press, 2008).

Marmor, Andrei, "Preface," in Law and Interpretation: Essays in Legal Philosophy, ed. by Andrei Marmor (New York: Oxford University Press, 1995).

The Language of Law (New York: Oxford University Press, 2014).

Nussbaum, Martha, "Legal Reasoning," in The Cambridge Companion to the Philosophy of Law, ed. by John Tasioulas (Cambridge: Cambridge University Press, 2020).

Paul, Sarah K., Philosophy of Action (New York: Routledge, 2021).

Perry, Stephen, "Hart's Methodological Positivism," in Hart's Postscript: Essays on the Postscript to The Concept of Law, ed. by Jules Coleman, 311-354 (New York: Oxford University Press, 2001).

Postema, Gerald, Utility, Publicity, and Law: Essays on Bentham's Moral and Legal Philosophy (New York: Oxford University Press, 2019).

Raz, Joseph, The Authority of Law (Oxford: Clarendon Press, 1979).

, The Morality of Freedom (New York: Oxford University Press, 1986).

, Ethics in the Public Domain (New York: Oxford University Press, 1994).

Ross, Alf, On Law and Justice, ed. by Jakob Holtermann, trans. by Uta Bindreiter (Oxford: Oxford University Press, 2019).

Schauer, Frederick, "Social Science and the Philosophy of Law," in The Cambridge Companion to the Philosophy of Law, ed. by John Tasioulas, 95-114 (Cambridge: Cambridge University Press, 2020).

Searle, John, "Oxford Philosophy in the 1950s," in Philosophy, 90 (2015).

Shapiro, Scott J., "H.L.A. Hart," in A Companion to Analytic Philosophy, ed. by A.P. Martinich and David Sosa, 169-174 (Oxford: Blackwell Publishing Ltd., 2005).

Legality (Cambridge: The Belknap Press of Harvard University Press, 2011).

Simmons, A.J., Moral Principles and Political Obligations (New Jersey: Princeton University Press, 1979).

Simpson, A.W. Brian, Reflections on The Concept of Law (New York: Oxford University Press, 2011).

Soper, Philip, "Legal Theory and the Obligation of a Judge: The Hart/Dworkin Dispute," in Michigan Law Review, 75 (January 1977).

(c) 2021 Enrique Benjamin R. Fernando, III https://www.kritike.org/journal/issue 29/fernando december2021.pdf ISSN 1908-7330

(cc) BY-NC-ND 
Stavropoulos, Nicos, "Obligations, Interpretivism, and the Legal Point of View," in The Routledge Companion to Philosophy of Law, ed. by Andrei Marmor, 76-92 (New York: Routledge, 2017).

Stone, Martin, "Formalism," in The Oxford Handbook of Jurisprudence and Philosophy of Law, ed. by Jules Coleman and Scott Shapiro, 166-205 (New York: Oxford University Press, 2002).

Tasioulas, John, "Hart on Justice and Morality," in Reading HLA Hart's 'The Concept of Law', ed. by Luís Duarte d'Almeida, James Edwards, and Andrea Dolcetti, 155-176 (Oxford: Hart Publishing, 2013).

Toh, Kevin, "Four Neglected Prescriptions of Hartian Legal Philosophy," in Law and Philosophy, 33 (2014).

Twining, William and David Miers, How to Do Things with Rules, 5th ed. (Cambridge: Cambridge University Press, 2010).

Waismann, Friedrich, "Verifiability," in Proceedings of the Aristotelean Society, Supplementary Volumes, 19 (1945).

Waldron, Jeremy, "Normative (or Ethical) Positivism," in Hart's Postscript: Essays on the Postscript to The Concept of Law, ed. by Jules Coleman, 411-433 (New York: Oxford University Press, 2001).

Waluchow, W.J., Inclusive Legal Positivism (New York: Oxford University Press, 1994).

Wittgenstein, Ludwig, Philosophical Investigations, 4th ed., trans. by G.E.M. Anscombe, P.M.S. Hacker, and Joachim Schulte, ed. by P.M.S. Hacker and Joachim Schulte (West Sussex: Blackwell Publishing Ltd., 2009). 